\title{
Geochemistry and Mineralization of Some Selected Pegmatite Deposits in Panda North Central, Nigeria
}

\author{
I. Y. Tanko and P. Chime
}

\begin{abstract}
Pegmatite constitutes an important lithologic unit in the Precambrian Basement Complex of Panda north central Nigeria. The primary aim of this study is to present a geochemical data of various rock types in the area especially pegmatite in order to determine their geochemical classification and mineralization potential of some selected pegmatite deposits in the area. Geochemical analysis reveals that the pegmatite samples have high $\mathrm{SiO}_{2}$ content; 73.8-94.8 wt\%, low $\mathrm{Na}_{2} \mathrm{O} / \mathrm{K}_{2} \mathrm{O}$ ratio suggesting they are strongly peralkaline and peraluminous, indicating that the pegmatite may have formed from mixed plutonic sources. The discrimination diagram of $\mathrm{TiO}_{2}$ versus $\mathrm{SiO}_{2}$ shows that the samples plotted on both igneous and sedimentary field, but majorly on the igneous field which is an implication that substantial material may have been generated from igneous sources. Also the plotting of the pegmatite samples in both the tholeiitic and calc-alkaline fields shows that the magma from which the rock was formed was not totally restricted in occurrence only to subduction related environment but also from the oceanic crust of calc-alkaline environments. This is further confirmed by discrimination diagrams plot of $\mathrm{TiO}_{2}$ $\mathrm{K}_{2} \mathrm{O}-\mathrm{P}_{2} \mathrm{O}$ which indicates that substantial samples plotted fall within the continental crust. High potash content alkalies with relative Fe-enrichment and silica suggest the plutonic generation of magma and the development of the rocks in both the oceanic and continental crust. Major elements analysis of both the granitic rock aplite and biotite gneiss shows moderately high silica values. These values reflect the geochemical characteristic of crystalline rocks. The pegmatite of the study area exhibits low contents of $\mathrm{Nb}, \mathrm{Ta}, \mathrm{Ga}, \mathrm{Rb}$ and Sn which are the major mineralization indices for pegmatite bodies. In classifying the pegmatites, rare metal indicative elements were used to discriminate the barren ones from the mineralized. A plot of Ta-Ga reveals that all the samples plotted are below the boundary of mineralization line, suggesting all the pegmatite samples in the study area to be barren in term of rare earth metals and can be compared to other pegmatite bodies in Nigeria and around the world.
\end{abstract}

Index Terms - Geochemistry, mineralization, potential, pegmatite.

\section{INTRODUCTION}

The study area is within the Precambrian crystalline Basement Complex of Nigeria. The area under reference Panda consists of sandy layers, superficial clay and laterite underlain by biotite gneiss, aplite, pegmatite and schist. Pegmatite is extreme igneous rocks that form during the final stage of magma's crystallization. They are extreme because they contain exceptionally large crystals mixed with medium sized crystals and they sometimes contain minerals that are rarely found in other types of rocks.

Published on February 8, 2021.

I. Y. Tanko, Department of Geology and Mining, Nasarawa State University, Keffi, Nigeria.

(e-mail: iyantanko2014@gmail.com)

P. Chime, Department of Geology and Mining, Nasarawa State University, Keffi, Nigeria.
Crystal up to many meters long has been reported by [1] The primary mineralization of tantalum, niobium, tin, beryllium and lithium is hosted in large crystals of quartz, potassium feldspar, sodium rich plagioclase and muscovite pegmatite [2]. Pegmatite may compose of variety of minerals [3]. Nigeria metallogenic belt of $400 \mathrm{~km}$ hosting $\mathrm{Sn}-\mathrm{Nb}-\mathrm{Ta}-\mathrm{Zn}$ bearing pegmatite and other rare-metal mineralization have been regionally mapped by [4]. The belt trend SW to the north central Jos fields associated with the younger granites [5]. There is marked concentration of mineralized dykes in many parts of the north central Nigeria, for instance the wamba-Jama'a region, Keffi to Nasarawa area [6]. These areas are the important tin producing fields [6]. Two groups of pegmatites are noticeable in north central Nigeria [6]: (1) simple, barren pegmatite; the vast majority of pegmatite is simple. They consist mostly of coarse grained quartz, feldspar with subordinate mica and can be mined for feldspar or micas and (2) complex pegmatite are formed as a result of one long, continuous period of crystallization, during which the first formed minerals reacted with a progressive changing residual magmatic fluid. "Reference [6]" studies indicate that this change involves the development of a gaseous phase in the melt. A special feature of some complex pegmatite is the present of giant crystals within the inner zones. Abnormally large crystals of quartz, feldspar, mica, apatite, tourmaline and other minerals have been reported [6]. Gem quality stones such as topaz, garnet, tourmaline, cassiterite, tantalite, columbite and lepidolite are sought in such rocks. Many complex pegmatite are mined for metallic or rare earth constituents, they contain tantalum, niobium, beryllium, lithium, cerium, thorium and many other rare elements in a host of uncommon and complex minerals.

This study is focused at carrying out detailed field mapping to achieve the following specific objectives:(1) To produce a detail geologic map of the area on a scale of $1: 25,000$ (2) To identify the various rock types in the area especially pegmatite and determine their major, trace and rare-earth elements(REE) concentration. (3) To subject the data into statistical analysis for easier interpretation in other to mark out the degree of concentration of the elements in question and determine their geochemical classification and mineralization potential in the rock.

\section{Geological SETting}

\section{A. Regional Geology}

Nigeria lies within the Pan-African mobile belt, the West African craton to the west and Congo craton to the southeast (Fig.1). The belt is divided into two regions; the frontal region, at eastern margin of the west African craton which appears to have passed through a geosynclinals phase 
prior to the Pan-African event and the internal region, which is argued to have been affected by deformation. Within the sequence are domains of metasediments and metavolcanics intruded by igneous rocks, which constitute the north/south trending schist belts. The schist belt lithologies which consist of fine grained clastics, peliticschists, phyllites, banded iron-formations, marble and amphibolites are considered to be upper proterozoic assemblages [7] They host most of the economic minerals in the basement complex. During the Pan-Afican (600ma) episode, the proterozoic gneiss-migmatite-schist complex were intruded by various granitoids resulting from oceanic closure, subduction, oblique collision between the west African craton and the Hoggar-Nigeria shields [8] and crustal thickening. The end of the Pan-African tectonic event is marked by a conjugate fracture system of the strike slip fault. The Pan-African granitoids of Nigeria, which is collectively known as older granites, consists of gabbros, charnockites, diorites, granites and syenites. Pegmatites and rare mineralization are closely associated with the fractures in the Pan-African belt [9], [10]. About 100km north-east of the area of study at wamba, rare metal pegmatites have also been geochemically linked to peraluminous late PanAfrican tectonic granitoids, the emplacement of which have largely been controlled by the regional fractures [9].

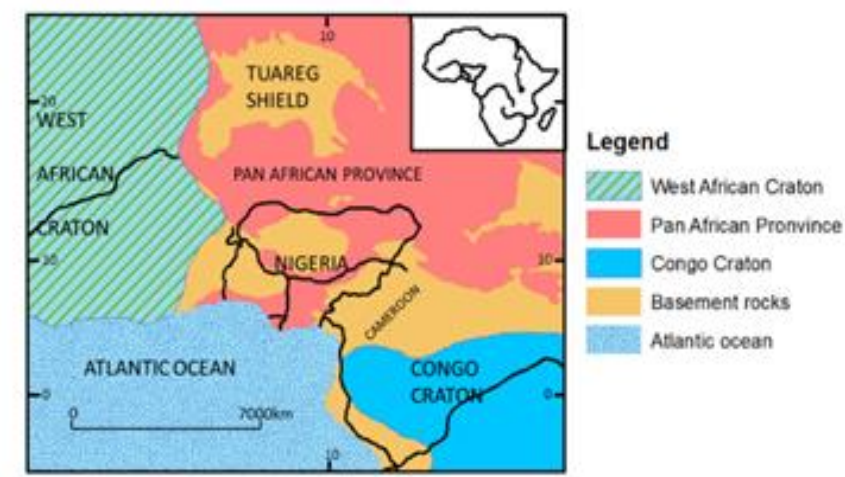

Fig. 1 The geologic setting of Nigeria showing WestAfrican Craton [7]

\section{B. Previous Work}

Previous works on the study area forms part of the pegmatites zones of Basement complex extending from southwestern to Central Nigeria. The pegmatites of north central Nigeria have been documented by various workers [6], [5] were among the first researches to document on the pegmatites of Wamba area, North central, Nasarawa State, Nigeria. "Reference [11]" carried out more detailed work on pegmatites of wamba-Jama'a region of the Plateau province and Kabba province; He noted the occurrences of tantalite and cassiterite mineralization on them. He also recognized the two periods and style of mineralization in Nigeria pegmatites but [6] have genetically linked the pegmatites to the so called "Older granites" and discussed them with regard to African magmatic activity. Contrarily, [12] carried out studies on the barren and mineralized pegmatites of Central and Southwestern Nigeria and indicated that the pegmatite emplacement occurred at the end of Pan-Arican magmatic activity (562-534 Ma). The regional geochemical mapping of the Wamba pegmatites field was done by [9] and reported the occurrence of emerald, ruby, topaz, tourmaline and aquamarine is association with pegmatites of the Wamba pegmatites field of central Nigeria. He further established the existence of two sets of pegmatites; NW-SE and E-W, trend with the former highly mineralized with rare-metals and gem minerals than the later.

Some workers like [2], [9] have done localized studies of chemical compositional characteristics in relation to cassiterite mineralization and the Pan-African Granitic evolution. The geological heavy mineral survey for $\mathrm{Nb}-\mathrm{Sn}$ Ta mineralization carried out by [2] identified two stages of mineralization in Nigeria, the earliest been related to the palaeozoic granites while the last stage of mineralization is found in younger granites. [2], [13] did a regional geological study of rare-metal pegmatites, revealing at least 3000 sizeable veins ranging between $10-1500 \mathrm{~m}$ in length and sometimes up to $50 \mathrm{~m}$ in width distributed across and beyond earlier defined belt with diver's structural orientation and morphological composition [13] followed it up with localized study of the geochemical potentials of Ta$\mathrm{Nb}$ mineralization in some pegmatite occurrences in central Nigeria.

The metallogeny of the rare metal Ta-Na pegmatites of Nigeria were broadly classified into 7 broad fields [10], [13] namely Ijero- Aramoko, keffi-Nasarawa, Kabba-Isanlu, Kusha-Birn Gwari, Lema-Ndeji, Oke-Ogun and IbadanOsogbo. Recently [14] focuses on the petrography and mineralogy of the pegmatites as well as the host rocks to identify the petrographic indicators to the mineralization in the pegmatites of Keffi area, this is a follow up to the field feature and mode of emplacement of the pegmatites of Keffi area [15].

\section{METHODS OF STUDY}

The field investigation was carried out in two (2) stages, first was a reconnaissance survey for three days to identify existing pegmatite deposit(s) in the study area, followed by the second field visit during which geological field mapping on a scale of 1:25,000 was undertaken with the help of a topographical map, geologic hammer, compass-clinometers and GPS. Pegmatite deposits were located on the map of the study area using the coordinates obtained with the aid of the GPS from the field using a paper coordinator. This process starts by gridding the entire map both latitudinal and longitudinally into one minute each Fig. 2.

The different outcrops investigated include pegmatite, aplite, biotite gneiss, and schist. Generally, the outcrops in the study area are massive outcrops and relatively low (below $5 \mathrm{~m}$ ) with gentle to steep cliffs. The rock samples collected during the field work were subjected to laboratory work which involved sample preparation and geochemical analysis of major oxide, trace elements and rare earth metals to determine the mineralization potential of the pegmatite samples.

A total of fifteen (15) rock samples were selected for geochemical study: seven (7) pegmatite representative sample and two (2) host rocks, were selected for geochemical analysis in the determination of major, trace and REE metals was carried out using Energy Dispersive 
X-ray fluorescent (EDXRF) techniques at the Nigeria Geological Survey Agency; national geosciences research laboratory (NGRL), Kaduna.

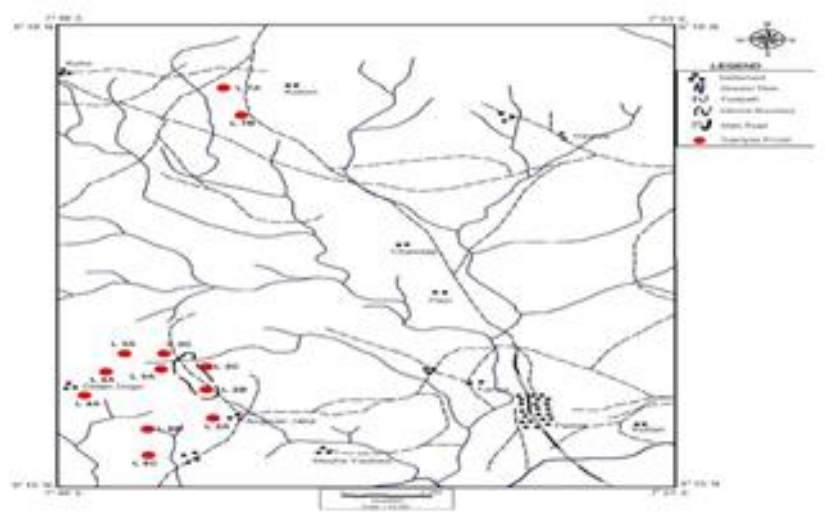

Fig. 2 Map of the study area showing sample collection points.

\section{A. Sampling, Preparation and Analytical Methods}

A total of seven (7) pegmatite samples and two (2) host rocks aplite and biotite gneiss were selected for geochemical analysis. About $1 \mathrm{~kg}$ of each sample was broken into pieces with a hammer and crushed about $1 \mathrm{~kg}$ from a large bulk sample. The samples were pulverized grind to fine powder using agate pulverizing machine (planetary micro mill pulverisette 7). The ground samples were ensured to pass 75 micro mesh sieves. This was to ensure homogeneity of the samples. As a means of pelletization, $5 \mathrm{~g}$ of the pulverized sample was weighed into a beaker, $1 \mathrm{~g}$ of binding aid starch soluble. The mixture was thoroughly mixed to ensure homogeneity, which was pressed under high pressure (6 tones") to produced pellets; labeled and package ready for the analysis.

The analytical procedure involved Energy Dispersive $\mathrm{x}$ ray fluorescence (EDXRF) spectrometer of model "minipal 4" was used for the analysis. LOI was determined gravimetrically by heating $1 \mathrm{~g}$ of the powdered sample in a cleaned weighed crucible at $1000{ }^{\circ} \mathrm{C}$ for $1 \mathrm{hr}$. After which the crucible and the content was weighed to get the difference in weight before and after heating. The samples were analysed at the National Geosciences Research Laboratory (NGRL), Kaduna using Energy Dispersive Xray fluorescence techniques to determine the concentration of elements in the samples.

\section{LOCAL GEOLOGY}

The results obtained using methodologies discussed in the previous chapter are presented in this chapter. The study area composed of low-lying pegmatite, aplite, biotite gneiss and schist Fig. 3. Contact relationships between the various rock types are commonly sharp although gradational contacts were also encountered. The study area is part of the Nigeria basement complex, a polycyclic terrain that has responded to various tectonic events within the Pan African orogeny [16]. Joints and fractures are the major structures observed in the area.

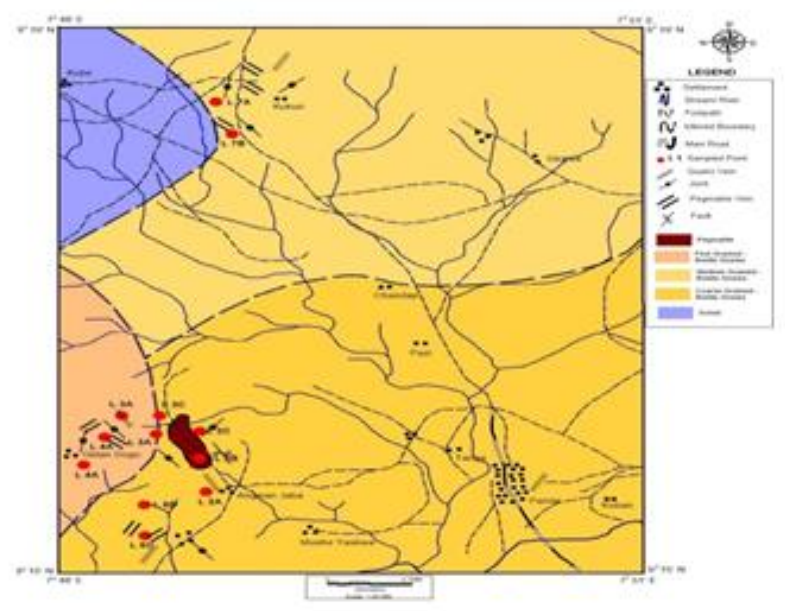

Fig. 3 Geological map of the study area

\section{GEOCHEMISTRY}

This section analyses and interprets the results of the geochemical investigation of the pegmatite samples and host rocks in the area. This is to enable the classification and determination of their mineralization potential.

\section{A. Major Oxides in Pegmatite}

The concentration of the major element oxides of the pegmatite from the study area are presented in Table 1 and geochemical classification of major oxide with some ration are presented in Table II, while trace and rare earth element concentration (ppm) are presented in Table IV.

TABLE I: AVERAGE CONCENTRATION OF MAJOR OXIDES (WT \%) IN

\begin{tabular}{cccccccc}
\multicolumn{7}{c}{ SAMPLES OF PEGMATITES } \\
\hline $\mathrm{S} / \mathrm{ID}$ & L2A & L2B & L3A & L3C & L4A & L6C & L7B \\
\hline $\mathrm{SiO}_{2}$ & 84.800 & 94.800 & 86.300 & 78.400 & 73.800 & 85.500 & 87.200 \\
$\mathrm{Al}_{2} \mathrm{O}_{3}$ & 4.420 & 0.630 & 2.020 & 1.860 & 1.030 & 2.400 & 1.000 \\
$\mathrm{SO}_{3}$ & 0.001 & 0.0007 & 0.002 & 0.0006 & 0.0007 & 0.002 & 0.0009 \\
$\mathrm{P}_{2} \mathrm{O}_{5}$ & 0.0008 & 0.002 & 0.001 & 0.0007 & 0.0006 & 0.001 & 0.002 \\
$\mathrm{Na}_{2} \mathrm{O}$ & 1.050 & 0.030 & 2.000 & 0.340 & 1.230 & 3.060 & 2.000 \\
$\mathrm{~K}_{2} \mathrm{O}$ & 2.100 & 0.120 & 6.170 & 16.60 & 19.780 & 2.050 & 4.690 \\
$\mathrm{CaO}$ & 1.060 & 0.140 & 1.050 & nd & 0.910 & 1.720 & 0.960 \\
$\mathrm{MgO}$ & 0.300 & 0.030 & 1.000 & 0.000 & 0.005 & 0.880 & 0.430 \\
$\mathrm{TiO}_{2}$ & 0.580 & 0.180 & 0.160 & 0.020 & 0.071 & 0.780 & 0.210 \\
$\mathrm{Fe}_{2} \mathrm{O}_{3}$ & 4.310 & 2.048 & 0.290 & 0.170 & 0.430 & 1.160 & 1.900 \\
$\mathrm{MnO}$ & 0.150 & 0.033 & 0.130 & 0.039 & 0.280 & 0.062 & 0.089 \\
$\mathrm{H}_{2} \mathrm{O}$ & 1.940 & 0.840 & 0.980 & 1.960 & 2.400 & 1.620 & 1.010 \\
\hline
\end{tabular}

\section{B. Major Element Composition and Variation}

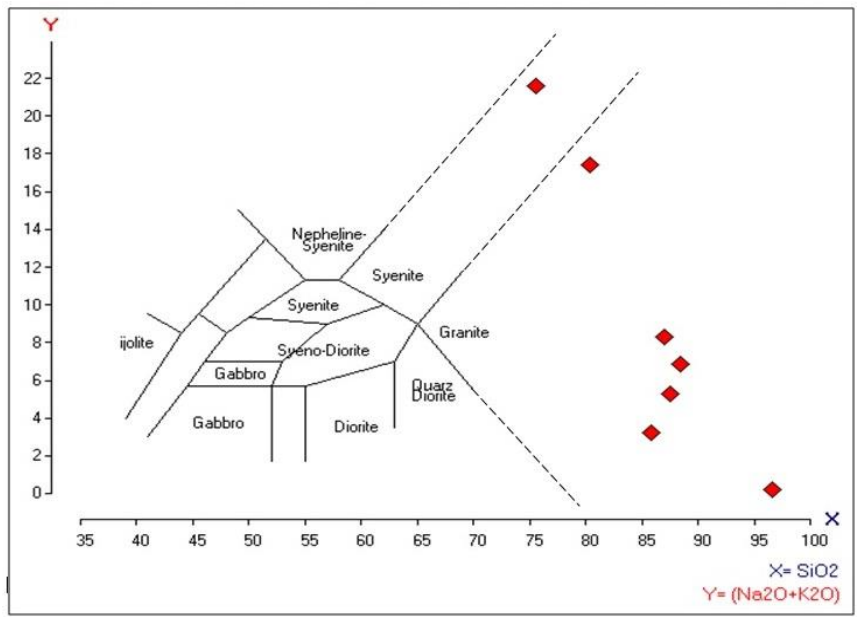

Fig. 4. TAS plot showing the granitic protolith of the samples [17]. 
The data show a wide compositional range of the pegmatites with a very high silica, $\mathrm{SiO}_{2}$ content (73.8$94.8 \mathrm{wt} \%)$ and alumina $\mathrm{Al}_{2} \mathrm{O}_{3} \quad(0.63-4.42 \quad \mathrm{wt} \%)$ of moderately low content. The data reveal also that soda, $\mathrm{Na}_{2} \mathrm{O}$ varies between 0.03 and 3.06 wt $\%$ while potash, $\mathrm{K}_{2} \mathrm{O}$ ranges between 0.12 and $19.78 \mathrm{wt} \%, \mathrm{CaO}$ ranges between 0.14 and 1.72. These compositional values are typical of pegmatites. Iron content $\left(\mathrm{Fe}_{2} \mathrm{O}_{3}\right)$ is relatively moderate ranging between $0.29 \mathrm{wt} \%$ and $4.31 \mathrm{wt} \%$. However, these rocks are characterized by low content of $\mathrm{MnO}$ and $\mathrm{P}_{2} \mathrm{O}_{5}$ which is 0.11 and 0.001 wt. \%. Fig. 4 shows the Total Alkali Silica (TAS) plot, it indicates a plot of $\mathrm{SiO}_{2}$ against $\mathrm{Na}_{2} \mathrm{O}+\mathrm{K}_{2} \mathrm{O}$ showing the granitic protolith of the pegmatite. All the plots fall within the granite supporting the granitic character of pegmatites.

\section{Geochemical Classification}

TABLE II: MAJOR OXIDES WITH SOME RATIOS

\begin{tabular}{cccccccc}
\hline \multicolumn{1}{c}{ L2A } & L2B & L3A & L3C & L4A & L6C & L7B \\
\hline $\mathrm{S} / I D$ & 84.800 & 94.800 & 86.300 & 78.400 & 73.800 & 85.500 & 87.200 \\
$\mathrm{SiO}_{2}$ & 4.420 & 0.630 & 2.020 & 1.860 & 1.030 & 2.400 & 1.000 \\
$\mathrm{Al}_{2} \mathrm{O}_{3}$ & 0.001 & 0.0007 & 0.002 & 0.0006 & 0.0007 & 0 & 0.0009 \\
$\mathrm{SO}$ & 0.0008 & 0.002 & 0.001 & 0.0007 & 0.0006 & 0 & 0.002 \\
$\mathrm{P}_{2} \mathrm{O}_{5}$ & 1.050 & 0.030 & 2.000 & 0.340 & 1.230 & 3.060 & 2.000 \\
$\mathrm{Na}_{2} \mathrm{O}$ & 2.100 & 0.120 & 6.170 & 16.600 & 19.780 & 2.050 & 4.690 \\
$\mathrm{~K}_{2} \mathrm{O}$ & 0.500 & 0.250 & 0.324 & 0.020482 & 0.06218 & 1.490 & 0.4264 \\
$\mathrm{Na}_{2} \mathrm{O} / \mathrm{K}_{2} \mathrm{O}$ & 1.0499 & 2.1724 & 0.219 & 0.109799 & 0.04699 & 0.350 & 0.1307 \\
$\mathrm{CaO}_{2} \mathrm{O}_{3} /\left(\mathrm{Na}_{2} \mathrm{O}+\mathrm{K}_{2} \mathrm{O}+\mathrm{CaO}\right)$ & 1.060 & 0.140 & 1.050 & 0 & 0.910 & 1.720 & 0.960 \\
$\mathrm{MgO}$ & 0.300 & 0.030 & 1.000 & 0 & 0.005 & 0.880 & 0.430 \\
$\mathrm{TiO}_{2}$ & 0.580 & 0.180 & 0.160 & 0.020 & 0.071 & 0.780 & 0.210 \\
$\mathrm{Fe} \mathrm{O}_{3}$ & 4.310 & 2.048 & 0.290 & 0.170 & 0.430 & 1.160 & 1.900 \\
$\mathrm{MnO}$ & 0.150 & 0.033 & 0.130 & 0.039 & 0.280 & 0.060 & 0.089 \\
$\mathrm{H} 2 \mathrm{O}$ & 1.940 & 0.840 & 0.980 & 1.960 & 2.400 & 1.620 & 1.010 \\
\hline
\end{tabular}

\section{Discrimination Diagram of Major Oxides}

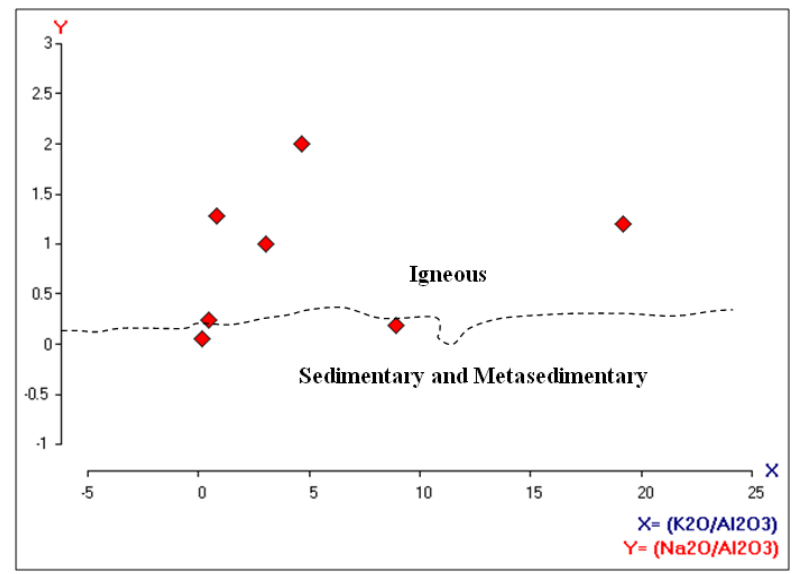

Fig. 5. $\mathrm{Na}_{2} \mathrm{O} / \mathrm{Al}_{2} \mathrm{O}_{3}$ vs. $\mathrm{K}_{2} \mathrm{O} / \mathrm{Al}_{2} \mathrm{O}_{3}$ plot for pegmatites [18].

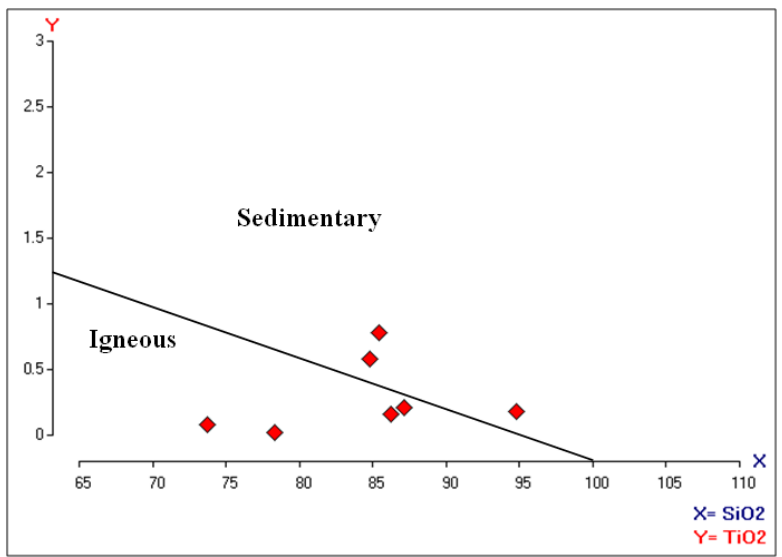

Fig. 6. $\mathrm{TiO}_{2}$ versus $\mathrm{SiO}_{2}$ Discrimination Diagram [19].

Fig. 5 above shows that the pegmatite samples plotted on both the igneous, sedimentary and metasedimentary origins as seen in a plot of $\mathrm{Na}_{2} \mathrm{O} / \mathrm{Al}_{2} \mathrm{O}_{3}$ versus $\mathrm{K}_{2} \mathrm{O} / \mathrm{Al}_{2} \mathrm{O}_{3}$ [18], supporting the derivation of materials that made up the rock from mixed sources. Fig. 6, the discrimination diagram of $\mathrm{TiO}_{2}$ versus $\mathrm{SiO}_{2}$ as proposed by [19] also shows that the samples plotted on both igneous and sedimentary field (Fig. 8) but majorly on the igneous field which is an implication that substantial materials may have been generated from igneous sources.

Fig. 7. An AFM diagram in terms of the Alkalies $\left(\mathrm{Na}_{2} \mathrm{O}+\mathrm{K}_{2} \mathrm{O}\right), \mathrm{Fe}_{2} \mathrm{O}_{3}$, and $\mathrm{MgO}$ shows that the samples plotted in both the tholeiitic and calc-alkaline fields (Fig. 7). The line separates the tholeiitic fields from the calc-alkaline fields. The tholeiitic rocks normally show stronger Fe enrichment relative to $\mathrm{Mg}$ than the calc-alkaline while the calc-alkaline shows enrichment in silica and alkalies [22]. The plotting of the samples in both the tholeiitic and calcalkaline fields shows that the magma from which the rock was formed was not totally restricted in occurrence only to Subduction-related environment. This suggests that the pegmatite may have been derived not only from subductiontectonic environment but also from the oceanic crust of calc-alkaline environments.

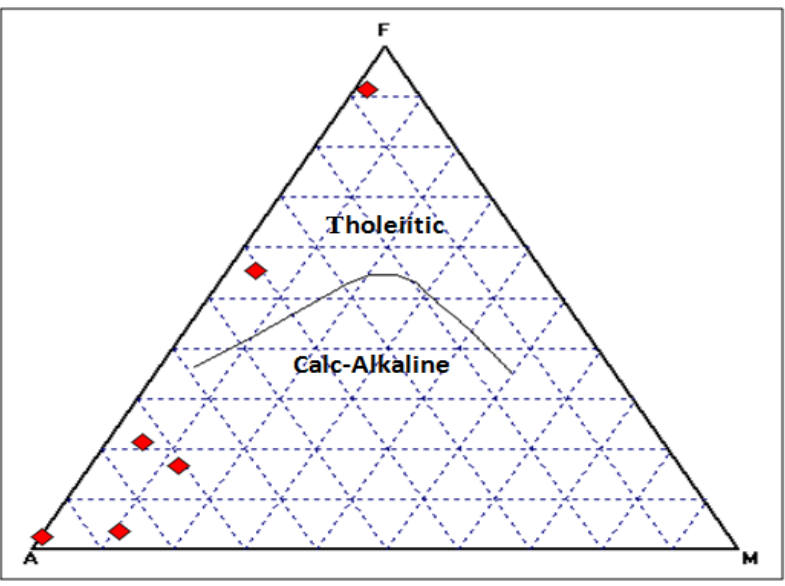

Fig. 7. AFM diagram for rocks in the study area discriminating calcalkaline field from tholeiitic [20]. 


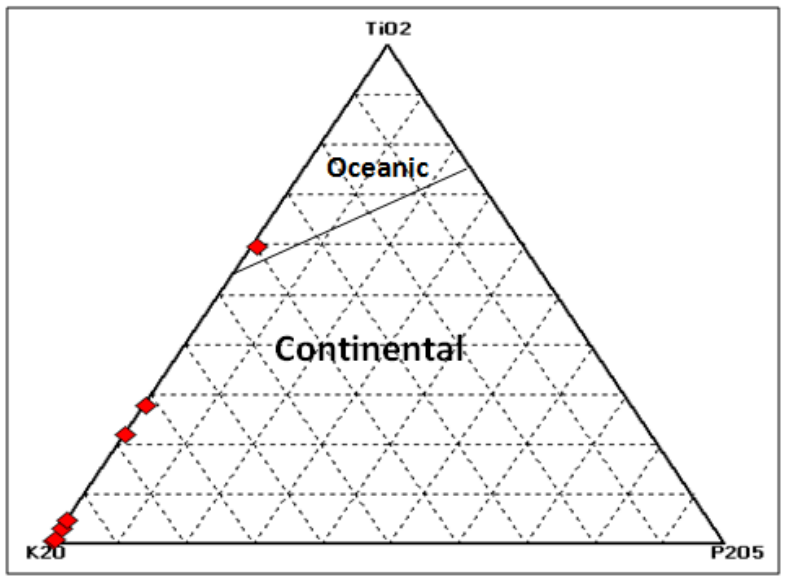

Fig. 8. $\mathrm{TiO}_{2}-\mathrm{K}_{2} \mathrm{O}-\mathrm{P}_{2} \mathrm{O}_{5}$ plot of the rocks [21].

The plot of $\mathrm{TiO}_{2}-\mathrm{K}_{2} \mathrm{O}-\mathrm{P}_{2} \mathrm{O}_{5}$ in Fig. 8 above indicates that substantial samples plotted in the continental crust. High potash content (alkalies) with relative Fe-enrichment and silica suggest the plutonic generation of magma and the development of the rocks in both the oceanic and continental crusts.

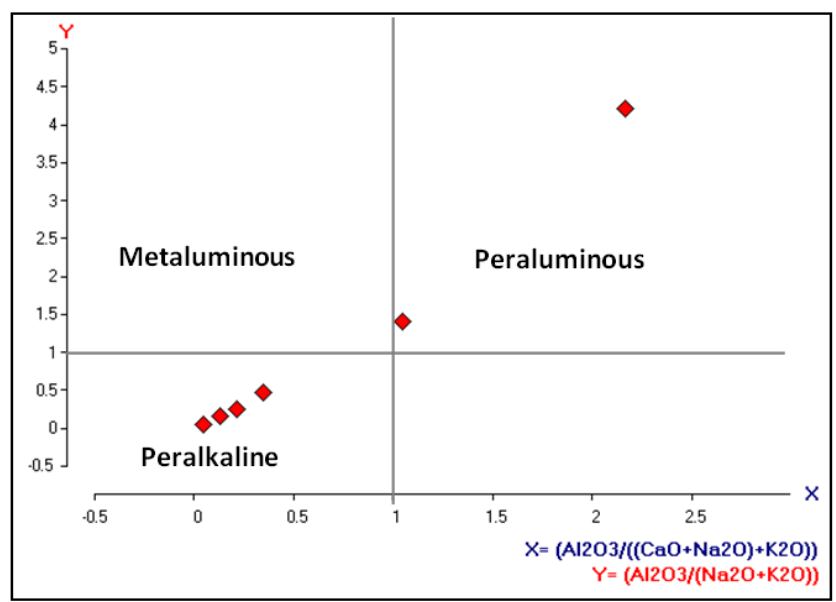

Fig. 9. $\mathrm{Al}_{2} \mathrm{O}_{3} /\left(\mathrm{CaO}+\mathrm{Na}_{2} \mathrm{O}+\mathrm{K}_{2} \mathrm{O}\right)$ versus $\mathrm{Al}_{2} \mathrm{O}_{3} / \mathrm{Na}_{2} \mathrm{O}+\mathrm{K}_{2} \mathrm{O}$ plot showing the dominantly Peralkaline nature of the rocks [22].

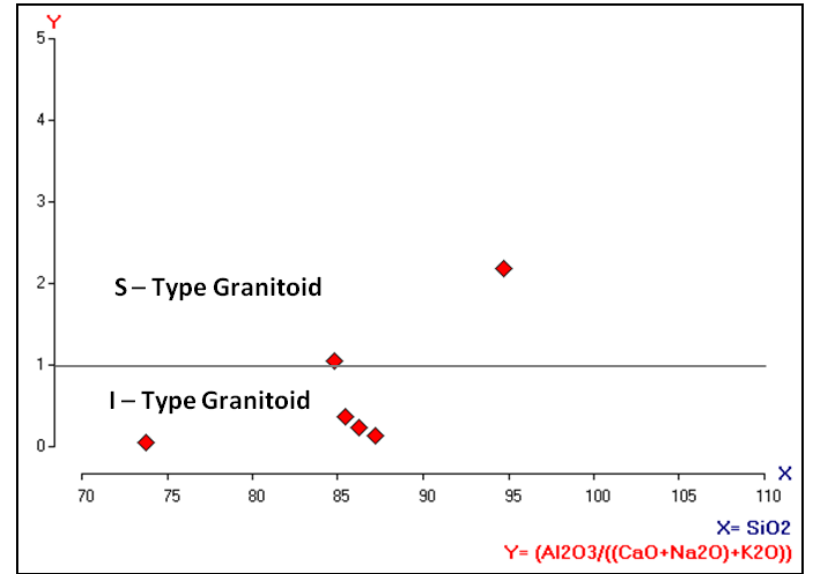

Fig. 10. Molecular $\mathrm{Al}_{2} \mathrm{O}_{3} / \mathrm{CaO}+\mathrm{Na}_{2} \mathrm{O}+\mathrm{K}_{2} \mathrm{O}$ versus $\mathrm{SiO}_{2}$ diagram showing the classification of the rocks into the fields of I-type and S-type granitoids [23].

Fig. 9 A plot of $\mathrm{Al}_{2} \mathrm{O}_{3} /\left(\mathrm{CaO}+\mathrm{Na}_{2} \mathrm{O}+\mathrm{K}_{2} \mathrm{O}\right)$ versus $\mathrm{Al}_{2} \mathrm{O}_{3} /\left(\mathrm{Na}_{2} \mathrm{O}+\mathrm{K}_{2} \mathrm{O}\right)$ in Figure 9 above shows the peralkaline character of the pegmatite as most of the samples plotted on the Peralkaline field.

Fig. 10 The molecular $\mathrm{Al}_{2} \mathrm{O}_{3} /\left(\mathrm{CaO}+\mathrm{Na}_{2} \mathrm{O}+\mathrm{K}_{2} \mathrm{O}\right)$ versus $\mathrm{SiO}_{2}$ shows the plotting majorly on the I-type granitoids (Fig.10). This implies a major source of the material is from igneous melt. Also, plots of rock in the Stype field imply that the original magma from which the pegmatite was formed contained great amount of sedimentary or crustal material. Reference [24] however, stated that similar granitic compositions can be produced by partial melting of a variety of sources. Reference [24], [25] were of the opinion that granitoids rarely come from single sources, but instead are mixtures of mantle-derived mafic melts and melts of crustal rocks that may or may not contain metasedimentary components.

\section{E. Major Oxidesi in Aplite and Biotite Gneiss}

This section analyses and interprets the results of the geochemical investigation of the aplite and biotite gneiss rocks in the area.

\section{F. Major Element Composition and Variation}

Major elements analysis of both the granitic rock (aplite, L3b) and gneiss (L6b) shows moderately high Silica $\left(\mathrm{SiO}_{2}\right)$ with values of 74.40 and $73.00 \mathrm{wt} \%$ respectively while alumina $\left(\mathrm{Al}_{2} \mathrm{O}_{3}\right)$ has values of 0.76 and $12.10 \mathrm{wt} \%$. The data also reveal the soda, $\mathrm{Na}_{2} \mathrm{O}$ to be 0.06 and $0.69 \mathrm{wt} \%$ while that of $\mathrm{K}_{2} \mathrm{O}$ is 22.20 and 3.08 wt\%. These values reflect the geochemical characteristics of crystalline rocks. The total alkali vs silica TAS diagram (Fig. 11) confirms sample L3b to be members of the Older granite suite as it plotted in the field of syenite while that of L6b plotted in the field of granite which is an indication of a granitic protolith.

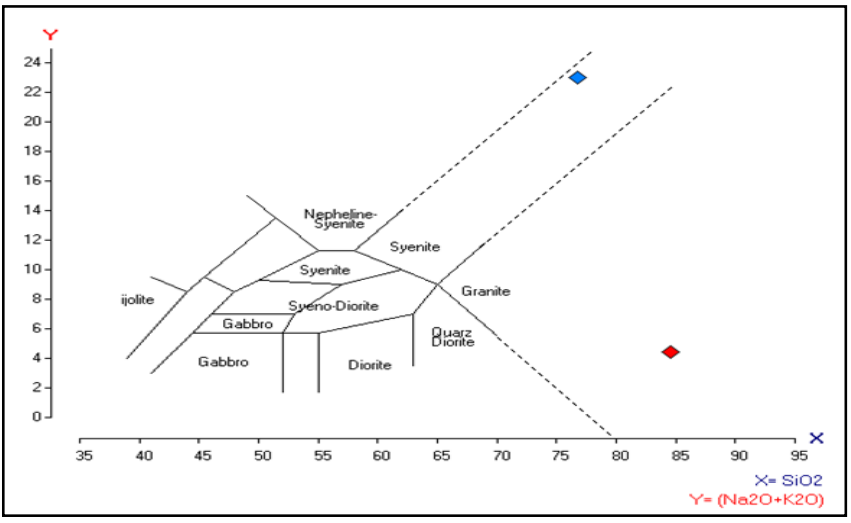

Fig. 11. TAS plot. 


\section{G. Discrimination Diagram of Major Oxides in Aplite and Biotite Gneiss}

The $\mathrm{Na}_{2} \mathrm{O} / \mathrm{Al}_{2} \mathrm{O}_{3}$ vs $\mathrm{K}_{2} \mathrm{O} / \mathrm{Al}_{2} \mathrm{O}_{3}$ plot Fig. 12 of [18] also confirms the igneous origin of the samples as all plotted in the igneous field. Meanwhile, the plot of $\mathrm{TiO}_{2}-\mathrm{K}_{2} \mathrm{O}-\mathrm{P}_{2} \mathrm{O}_{5}$ in Fig. 13 indicates that the samples plotted in the continental crust. High potash content (alkalies) with relative $\mathrm{Fe}$ enrichment and silica suggests the plutonic generation of magma and the development of the rocks.

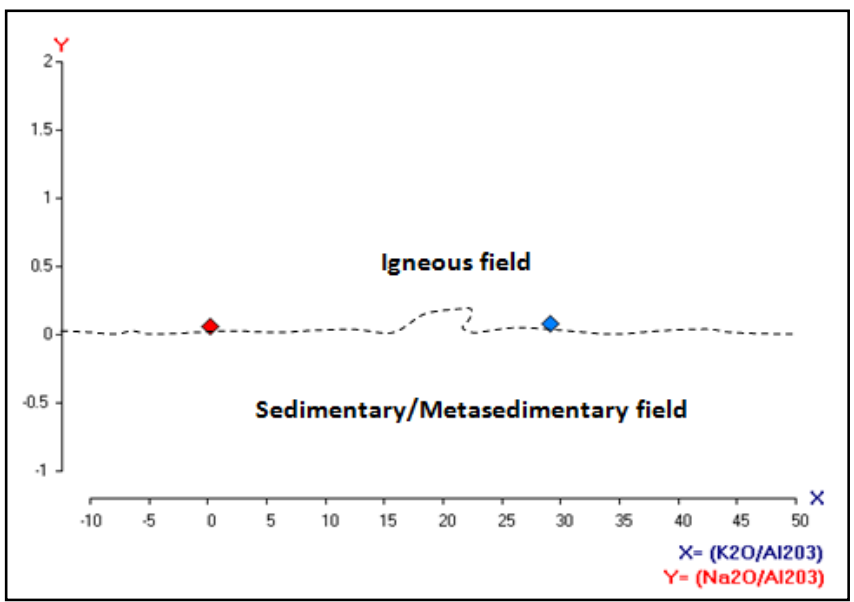

Fig. 12. $\mathrm{Na}_{2} \mathrm{O} / \mathrm{Al}_{2} \mathrm{O}_{3}$ vs $\mathrm{K}_{2} \mathrm{O} / \mathrm{Al}_{2} \mathrm{O}_{3}$ plot [18].

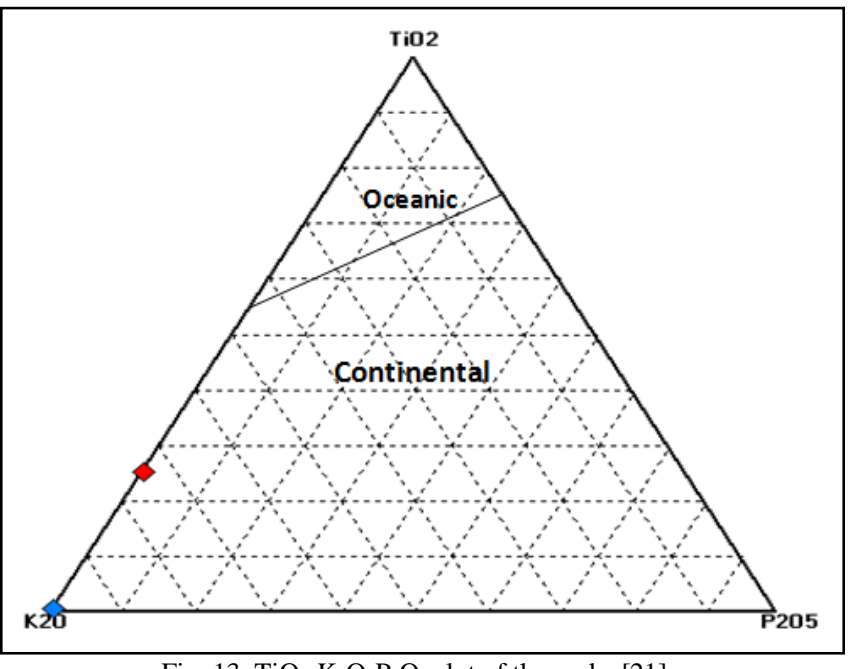

Fig. 13. $\mathrm{TiO}_{2}-\mathrm{K}_{2} \mathrm{O}-\mathrm{P}_{2} \mathrm{O}_{5}$ plot of the rocks [21].

\section{H. Trace and Rare Earth Element Composition in Pegmatite Samples}

In studying the mineralization potential of the pegmatite samples, certain geochemical parameters were observed in order to classify some of the pegmatites as barren or mineralized. The Table IV below presents the analysis of the trace and rare earth element.

TABLE IV: TRACE AND RARE EARTH ElEMENT CONCENTRATION (PPM) In SAMPLES OF PEgMATITES

\begin{tabular}{cccccccc}
\hline Sample ID & L2A & L2B & L3A & L3C & L4A & L6C & L7B \\
\hline $\mathrm{V}$ & 0.009 & 0.002 & nd & nd & 0.010 & 0.020 & nd \\
$\mathrm{Cr}$ & nd & 0.0074 & nd & nd & 0.032 & nd & nd \\
$\mathrm{Ru}$ & 0.055 & 0.290 & 0.350 & 0.470 & 0.440 & 0.520 & 0.380 \\
$\mathrm{Ba}$ & 0 & 0.020 & 0.093 & 0.051 & 0.310 & 0 & 0.073 \\
$\mathrm{Sr}$ & 0.087 & nd & 0.040 & 0.170 & 0.100 & 0.192 & 0.072 \\
$\mathrm{Rb}$ & 0.002 & nd & 0.066 & 0.120 & 0.160 & 0.049 & 0.084 \\
$\mathrm{Ba} / \mathrm{Rb}$ & 0 & nd & 1.409091 & 0.425 & 1.9375 & 0 & 0.869048 \\
$\mathrm{Zr}$ & 0.024 & nd & nd & 0.003 & 0.023 & 0.044 & 0.018 \\
$\mathrm{Cu}$ & 0.045 & 0.029 & 0.023 & 0.073 & 0.043 & 0.041 & 0.100 \\
$\mathrm{~Pb}$ & 1.870 & 0.020 & 0.010 & 0.063 & nd & 0.036 & 0.008 \\
$\mathrm{Eu}$ & 0.340 & 0.130 & 0.071 & nd & nd & 0.100 & 0.100 \\
$\mathrm{As}$ & nd & 0.006 & 0.0074 & 0.007 & 0.019 & 0.005 & 0.009 \\
$\mathrm{Ti}$ & nd & 0.051 & nd & nd & nd & nd & nd \\
$\mathrm{Ce}$ & nd & nd & nd & nd & nd & 0.046 & nd \\
$\mathrm{Ta}$ & 0.078 & nd & 0.021 & 0.087 & 0.054 & nd & 0.087 \\
$\mathrm{Nb}$ & 0.025 & nd & 0.040 & 0.085 & 0.162 & nd & 0.090 \\
$\mathrm{Ga}$ & 0.016 & 0.004 & 0.011 & 0.003 & 0.010 & 0.0062 & 0.013 \\
$\mathrm{Zn}$ & 0.098 & 0.021 & nd & nd & 0.004 & 0.006 & nd \\
$\mathrm{Bi}$ & 0.033 & nd & nd & nd & nd & nd & nd \\
$\mathrm{Re}$ & 0.050 & 0.027 & 0.039 & nd & 0.040 & 0.037 & 0.013 \\
$\mathrm{Pr}$ & nd & 0.024 & 0.048 & nd & nd & nd & 0.023 \\
$\mathrm{Y}$ & nd & nd & 0.025 & 0.003 & 0.010 & nd & 0.006 \\
$\mathrm{Hg}$ & nd & nd & 0.020 & nd & ooo1 & nd & nd \\
$\mathrm{Er}$ & nd & nd & nd & 0.010 & nd & nd & nd \\
$\mathrm{Os}$ & nd & nd & nd & 0.007 & 0.020 & nd & 0.007 \\
$\mathrm{Se}$ & nd & nd & nd & 0.028 & 0.026 & nd & nd \\
$\mathrm{Ge}$ & nd & nd & nd & nd & 0.010 & nd & 0.005 \\
$\mathrm{Sb}$ & nd & nd & nd & nd & nd & 0.017 & nd \\
$\mathrm{Sn}$ & nd & nd & nd & nd & nd & 0.024 & nd \\
$\mathrm{W}$ & 0.008 & nd & 0.010 & 0.005 & 0.004 & nd & 0.021 \\
\hline & & & & & & &
\end{tabular}

\section{Trace and Rare Earth Element Composition and Variation}

In classifying the pegmatites, rare metal indicative elements such as $\mathrm{Ta}, \mathrm{Nb}, \mathrm{Ga}$ and $\mathrm{Sn}$ were used to discriminate the barren ones from the mineralized pegmatite. The values of the aforementioned were as small as seen in the table above and this point to the fact that they may be barren in terms of rare earth metals. The plot of Ta-
Ga above [26] reveals the $\mathrm{Ta}-\mathrm{Nb}$ mineralization potential trend. It shows that all the samples plotted far below the boundary of mineralization line, suggesting all the pegmatite samples to be barren in term of rare earth metals. 


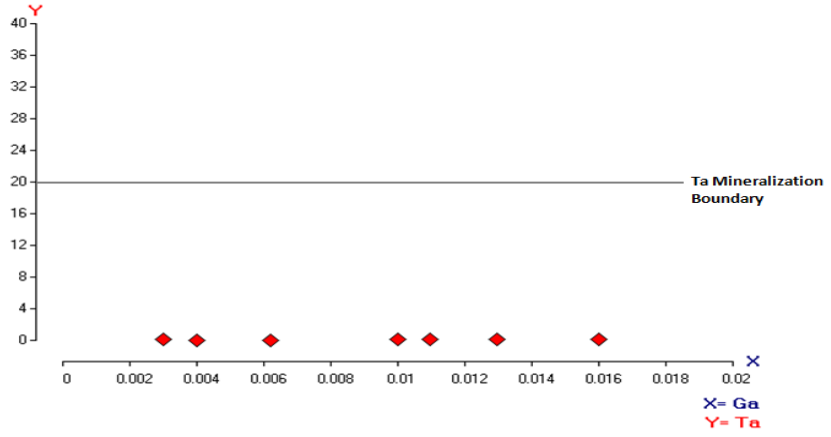

Fig. 14. The Ta-Ga plot showing the mineralization boundary [26]

\section{DISCUSSION}

\section{A. Pegmatites Geochemistry}

Major element distribution shows that the pegmatites are siliceous; with $\mathrm{SiO}_{2}$ content ranging between 73.8-94.8\%; this value is higher than average values of mineralized pegmatite reported by [27] but comparable to the Ipetu Ijesha barren pegmatites [28] , Ago-Iwoye barren pegmatites [29]. From the analytical result of major element concentration, $\mathrm{SiO}_{2}$ has the highest percentages in the pegmatite samples while $\mathrm{P}_{2} \mathrm{O}_{5}, \mathrm{TiO}_{2}, \mathrm{Al}_{2} \mathrm{O}_{3}, \mathrm{~K}_{2} \mathrm{O}, \mathrm{Na}_{2} \mathrm{O}$, $\mathrm{CaO}$ and $\mathrm{MnO}$ are relatively low. Mean contents major oxides, $\mathrm{Al}_{2} \mathrm{O}_{3}, \mathrm{Na}_{2} \mathrm{O}, \mathrm{Fe}_{2} \mathrm{O}_{3}, \mathrm{CaO}$, and $\mathrm{K}_{2} \mathrm{O}$ for Panda pegmatites compared favorably with the Ipetu Ijesha barren pegmatites, Kafin Maiyaki barren pegmatites and AgoIwoye barren pegmatites [28], [10], [13], [29].

Variation plot of $\mathrm{SiO}_{2}$ against $\mathrm{Na}_{2} \mathrm{O}+\mathrm{K}_{2} \mathrm{O}$ reveal the granitic protolith of the pegmatite. To support the derivation of materials that made up the rock from mixed sources, a plot of $\mathrm{Na} 2 \mathrm{O} / \mathrm{Al} 2 \mathrm{O} 3$ versus $\mathrm{K} 2 \mathrm{O} / \mathrm{Al} 2 \mathrm{O} 3$, shows that the pegmatite samples plotted are from igneous, sedimentary and metasedimentary origins (Fig. 5). This was further confirmed by the discrimination plot of $\mathrm{TiO}_{2}$ versus $\mathrm{SiO}_{2}$ as proposed by [19], which shows that the samples plotted on both igneous and sedimentary field (fig.6) but that majority of plot fall within the igneous field which is an implication that substantial materials may have been generated from igneous sources. Furthermore, an AFM diagram in terms of the Alkalies $\left(\mathrm{Na}_{2} \mathrm{O}+\mathrm{K}_{2} \mathrm{O}\right), \mathrm{Fe}_{2} \mathrm{O}_{3}$, and $\mathrm{MgO}$ shows that the samples plotted in both the tholeiitic and calc-alkaline fields (Fig. 11). The line separates the tholeiitic fields from the calc-alkaline fields. The tholeiitic rocks normally show stronger $\mathrm{Fe}$-enrichment relative to $\mathrm{Mg}$ than the calcalkaline while the calc-alkaline shows enrichment in silica and alkalies [30]. The plotting of the samples in both the tholeiitic and calc-alkaline fields shows that the magma from which the rock was formed was not totally restricted in occurrence only to Subduction-related environment. This suggests that the pegmatite may have been derived not only from subduction-tectonic environment but also from the oceanic crust of calc-alkaline environments. Meanwhile, the plot of TiO2-K2O-P2O5 in (Fig.12) indicates that substantial samples plotted in the continental crust. High potash content (alkalies) with relative Fe-enrichment and silica suggest the plutonic generation of magma and development of the rocks in both the oceanic and continental crusts.

A plot of $\mathrm{Al}_{2} \mathrm{O}_{3} /\left(\mathrm{CaO}+\mathrm{Na}_{2} \mathrm{O}+\mathrm{K}_{2} \mathrm{O}\right)$ versus $\mathrm{Al}_{2} \mathrm{O}_{3} /$ $\left(\mathrm{Na}_{2} \mathrm{O}+\mathrm{K}_{2} \mathrm{O}\right)$ in Fig. 13 reveals the peralkaline character of the pegmatite as most of the samples plotted on the peralkaline field, while few plotted in the peraluminous field. This implies that a major source of the material is from igneous melt. The diagnostic minerals in strongly peralkaline rocks are the sodic amphiboles and pyroxenes, while in strongly peraluminous granitoids, the phase can be muscovite, cordierite, garnet, but they are commonly taken to have formed from a sedimentary source. Strongly peraluminous melts may form by melting of biotite-bearing metaluminous felsic rocks or even by water-excess melting of mafic rocks. While the molecular plot of $\mathrm{Al} 2 \mathrm{O} 3 /(\mathrm{CaO}+\mathrm{Na} 2 \mathrm{O}+\mathrm{K} 2 \mathrm{O})$ versus $\mathrm{SiO} 2$ shows the plotting majorly fall on the I-type granitoids. This implies a major source of the material is from igneous melt (Fig.10) Also plots of rock in the S-type field imply that the original magma from which the pegmatite was formed contained great amount of sedimentary or crustal material, however stated that similar granitic compositions can be produced by partial melting of a variety of sources. Reference [25] is of the opinion that granitoids rarely come from single sources, but instead are mixtures of mantle-derived mafic melts and melts of crustal rocks that may or may not contain metasedimentary components.

\section{B. Aplite and Biotite Gneiss Geochemistry}

The major elements distribution in aplite, L3b and biotite gneiss L6b show moderately high silica $\left(\mathrm{SiO}_{2}\right)$ with values of 74.40 and $73.00 \mathrm{wt} \%$ respectively, while alumina $\left(\mathrm{Al}_{2} \mathrm{O}_{3}\right)$ has values of 0.76 and $12.10 \mathrm{wt} \%$. The data also reveal the soda, $\mathrm{Na}_{2} \mathrm{O}$ to be 0.06 and 0.69 wt $\%$ while that of $\mathrm{K}_{2} \mathrm{O}$ is 22.20 and $3.08 \mathrm{wt} \%$. These values reflect the geochemical characteristics of crystalline rocks. The total alkali vs silica TAS diagram (Fig. 11) confirms sample L3b to be members of the older granite suite as it plotted in the field of syenite while that of L6b plotted in the field of granite which is an indication of a granitic protolith. Furthermore, a plot of $\mathrm{Na}_{2} \mathrm{O} / \mathrm{Al}_{2} \mathrm{O}_{3}$ vs $\mathrm{K}_{2} \mathrm{O} / \mathrm{Al}_{2} \mathrm{O}_{3}$ (fig.12) also confirms the igneous origin of the samples as all plotted in the igneous field. Meanwhile, plot of $\mathrm{TiO}_{2}-\mathrm{K}_{2} \mathrm{O}-\mathrm{P}_{2} \mathrm{O}_{5}$ in (Fig. 13) indicates that the samples plotted in the continental crust. The high potash content (alkalies) with relative $\mathrm{Fe}$ enrichment and silica suggest the plutonic generation of magma and the development of the rocks.

\section{Geochemical Features and Mineralization Potential of the Pegmatite Samples}

Table 4 shows the trace and rare earth element contents in the pegmatite of Panda area. For example, Rubidium- Rb (0.002-0.084ppm), Tantalum-Ta (0.078-0.087ppm), Niobium- $\quad \mathrm{Nb} \quad(0.025-0.090 \mathrm{ppm}), \quad$ Yttrium-Y(0.025$0.006 \mathrm{ppm})$, Tin-Sn (0.024), Strontim-Sr (0.087-0.072ppm). These characteristic indicate low concentration of the rare metals mineralization potentials in the pegmatite, significantly lower than the averages for the rare metal pegmatites of Ijero-Aramoko-Ara, Kushaka-Birni Gwari, Oke-Ogun, Isanlu-Egbe and keffi area [15] but are comparable to the Ilesha barren pegmatites [28], [22] Nasarawa-Kafin-Maiyaki barren pegmatites, [10] and AgoIwoye barren Pegmatites [29]. The black tourmalines observe in the pegmatite of panda area probably resulted from hypothermal process and it involves not only the water that is undissolved from the hot magma, but also involved 
rainwater. This mix of water, mineral and iron Fe element tends to fill the cracks in the magma as it cools and hardens into rock. As a result, black tourmaline and other similary created gem can be found in large veins.

The mineralization potential of Panda pegmatite was determined with the help of Ta-Ga plot. In classifying the pegmatites, rare metal indicative elements such as $\mathrm{Ta}, \mathrm{Nb}$, $\mathrm{Ga}$ and $\mathrm{Sn}$ were used to discriminate the barren ones from the mineralized. The values of the aforementioned were so small as seen in Table IV and this point to the fact that they may be barren. The Ta-Nb mineralization potential trend as shown from plot of Ta versus Ga (Fig.14), the plotting fall far below the boundary of mineralization line, [26] suggesting all the pegmatite samples to be less mineralize in term of rare earth metals. From variation plots of Ta versus Ga (Fig.14), Panda pegmatites have common features of the Nigeria pegmatite and can be compare with the barren pegmatites of Nasarawa and Kafin Maiyaki Northern Nigeria [10], Itakpe Area Central Nigeria [30]. The very low Ta contents in the pegmatite of the study area can be attributed to the fact that $\mathrm{TaO}_{3}$ cannot enter the fully polymerized (A1Si) 04 network of the k-feldspar [31].

In addition, large deposits of pure feldspars, microcline, muscovite, quartz and gemstones which are currently being mined from the pegmatite when properly exploited can serve as a good source of revenue for the country.

\section{CONCLUSION}

In the light of the above discussions the following conclusion can be made.

The study area comprises of low-lying schist, pegmatite, aplite, fine grained biotite gneiss, medium grained biotite gneiss, and coarse grained biotite gneiss. Geochemical analysis reveals that the pegmatites samples have high $\mathrm{SiO}_{2}$ content; 73.8-94.8 wt\%, low $\mathrm{Na}_{2} \mathrm{O} / \mathrm{k}_{2} \mathrm{O}$ ratio which suggest they are strongly peralkaline and peraluminous, indicating that the pegmatite may have formed from mixed plutonic sources. The discrimination diagram of $\mathrm{TiO}_{2}$ versus $\mathrm{SiO}_{2}$ shows that the samples plotted on both igneous and sedimentary field, but majorly on the igneous field which is an implication that substantial materials may have been generated from igneous sources (Fig. 6). Also the plotting of the pegmatite samples in both the tholeiitic and calcalkaline fields show that the magma from which the rock was formed was not totally restricted in occurrence only to subduction-related environment but also from the oceanic crust of calc-alkaline environments (Fig. 7). This is further confirmed by discrimination diagrams plot of $\mathrm{TiO}_{2}-\mathrm{K}_{2} \mathrm{O}-$ $\mathrm{P}_{2} \mathrm{O}_{5}$ in (Fig. 8) indicates that substantial samples plotted fall within the continental crust. The high potash content (alkalies) with relative Fe-enrichment and silica suggest the plutonic generation of magma and the development of the rocks in both the oceanic and continental crust. A plot of $\mathrm{Al}_{2} \mathrm{O}_{3} /\left(\mathrm{CaO}+\mathrm{Na}_{2} \mathrm{O}+\mathrm{K}_{2} \mathrm{O}\right)$ verse $\mathrm{Al}_{2} \mathrm{O}_{3} /\left(\mathrm{Na}_{2} \mathrm{O}+\mathrm{K}_{2} \mathrm{O}\right)$ in (fig. 9) shows the peralkaline character of the pegmatite as most of the samples plotted on the peralkaline field while the molecular $\mathrm{Al}_{2} \mathrm{O}_{3} /\left(\mathrm{CaO}+\mathrm{Na}_{2} \mathrm{O}+\mathrm{K}_{2} \mathrm{O}\right)$ versus $\mathrm{SiO}_{2}$ shows the plotting majorly on the I-type granitoids (Fig. 10). This implies a major source of the material is from igneous melt. Also, plots of rock in the S-type field imply that the original magma from which the pegmatite was formed contained great amount of sedimentary or crustal material.

Also geochemical analysis reveals that both the aplite and biotite gneiss shows moderately high silica $\left(\mathrm{SiO}_{2}\right)$ with values of 74.40 and $73.00 \mathrm{wt} \%$ respectively while alumina $\left(\mathrm{Al}_{2} \mathrm{O}_{3}\right)$ has values of 0.76 and $12.10 \mathrm{wt} \%$. These values reflect the geochemical characteristics of crystalline rocks. The total alkali vs silica TAS diagram (fig.11) confirms sample L3b to be members of the older granite suite as it plotted in the field of syenite while that of L6b plotted in the field of granite which is an indication of a granitic protolith. Furthermore, a plot of $\mathrm{Na}_{2} \mathrm{O} / \mathrm{Al}_{2} \mathrm{O}_{3}$ vs $\mathrm{K}_{2} \mathrm{O} / \mathrm{Al}_{2} \mathrm{O}_{3}$ (Fig. 12) also confirms the igneous origin of the samples as all plotted in the igneous field. Meanwhile, plot of $\mathrm{TiO}_{2-}$ $\mathrm{K}_{2} \mathrm{O}-\mathrm{P}_{2} \mathrm{O}_{5}$ in (Fig. 13) indicates that the samples plotted in the continental crust. The high potash content (alkalies) with relative Fe-enrichment and silica suggesting the plutonic generation of magma and the development of the rocks.

The pegmatites of the study area exhibit low contents of $\mathrm{Nb}, \mathrm{Ta} \mathrm{Ga}, \mathrm{Rb}$ and $\mathrm{Sn}$ which are the major mineralization indices for pegmatites bodies in Nigeria. In classifying the pegmatites, rare metal indicative elements were used to discriminate the barren once from the mineralized. A plot of Ta-Ga [26] reveals that all the samples plotted far below the boundary of mineralization line, suggesting all the pegmatite samples in the study area to be barren in term of rare earth metals (Fig. 14) and can be compared to other pegmatite bodies in Nigeria and around the world.

\section{REFERENCES}

[1] G. M. Best, "Igneous and Metamorphic Petrology". CBS Publ. \& Distr.New Delhi, India, 1981, pp 630.

[2] J. A. Kinnaird, "Contrasting Styles of Sn-Nb-Ta-Zn Mineralisation in Nigeria", Journal African Earth. Sciences, Vol. 2, No. 2, pp. 81 90.1984 .

[3] P. Bowden, and J.A. Kinnaird, "Geology and mineralization of the Nigerian anorogenic ring complexes”. Geol.Jb. B56, pp 3-65, 1984.

[4] G. Matheis, "Nigeria Rare-metal pegmatites and their lithological framework", Geological Journal Vol.22. pp 221-287., 1987.

[5] J.B.Wright, "Fracture Systems in Nigeria and Initiation of Fracture Zones in the South Atlantic", Tectonophysics, Vol. 34, pp. 743- 747. 1976.

[6] R. Jacobson, and J. S. Webb, "The Pegmatite of Central Nigeria",Geological Survey of Nigeria Bulletin, Vol. 17, 61pp. 1946.

[7] D. C. Turner, "Upper Proterozoic Schist Belts in the Nigerian Sector of the Pan-African Province of West Africa" Precambr. Res., Vol. 21, pp. $55-79.1983$.

[8] R. Black, "The Pan African event in the geological framework of Africa", Pangea 2, pp 6-16, 1984.

[9] D. Kuster, "Rare-Metal Pegmatites of Wamba, Central Nigeria-their Formation in Relationship to Late Pan-African Granites", Mineral Deposita, Vol. 25, pp. 25-33. 1990.

[10] I. Garba, "Geochemical discrimination of Newly Discovered Rare Metal Bearing and Barren Pegmatites in the Pan African $600 \pm 150$ Ma Basement of Northern Nigeria", Applied Earth Science Transaction Institute of Mining and Metallurgy, No. 13, Vol. 112, pp. 287-292. 2003.

[11] C. Raeburn, "The Tinfields of Nasarawa and Ilorin Provinces", Geological Survey of Nigeria, Bull. 5, pp1-64. 1924.

[12] G. Matheis, and M. Caen-Vachette, "Rb-Sr isotopic study of raremetal-bearing and barren pegmatites in the Pan-African reactivation zone of Nigeria". Journal of African Earth Sciences pp 34-40.1981.

[13] O.A Okunlola, "Metallogeny of Tantalite-Niobium Mineralization of Precambrian pegmatites of Nigeria”. Mineral wealth; 104/2005. pp 38-50, 2005.

[14] I.Y. Tanko, M. Adam and P.D. Dambring, "Mode of Emplacement of the Pegmatites of Keffi Area, North Central Nigeria". 
International Journal of Scientific 7 Technology Research, Vol. 4, Issue 4. Pp 214-229. 2015.

[15] I.Y. Tanko, "Petrogenesis and mineralization of the pegmatites of Keffi Area, North Central Nigeria", An Unpublished thesis of the University of Mines and Technology Tarkwa Ghana, Department of Geological Engineering.2014.

[16] S. S. Dada, "Proterozoic Evolution of Nigeria", In: The Basement Complex of Nigeria and its Mineral Resources (Oshin O. ed.), A Symposium organized to mark the 60th birthday of Prof. M. A. O. Rahaman, held at the Conference Centre, Obafemi Awolowo University, Ile - Ife, Nigeria, May 6th 2006, pp. 29-44.

[17] K. G. Cox, G. D. Bell, and R. J. Pankhurst, "The Interpretation of Igneous Rocks", George, Allen and Unwen, London. 1979, pp 2036.

[18] R. M. Garrels and F. T. Mackenzie, "Evolution of Igneous and Sedimentary Rocks", W.W. Norton and Company, Inc. New York, N.Y. 1971. pp394.

[19] J. Tarney, in "The Early Precambrian of Scotland and Related Rocks of Greenland eds Park, R.G. \& Tarney J. 1971, pp105 (University of Keele, 1973).

[20] T.N. Irvine and W.R.A., Baragar, "A Guid to the Chemical Classification of the common Volcanic Rocks". Cabadian Journal of Earth Science, Vol. 8, pp 523-548, 1971.

[21] J. A., Pearce, N. B. W., Harris, A. G. Tindle, "Trace Element Discrimination Diagram for the Tectonic Interpretation of Granitic Rocks", Journal of Petrology, Vol. 22, pp. 956-983. 1984.

[22] A. Miyashiro, "Metamorphic Petrology", Oxford University, Oxford, UK, 1974

[23] P.D. Maniar and P.M. Piccoli, "Tectonic discrimination of granitoids". Geological Society of America Bulletin101, pp. 635643. 1989.

[24] A. J. R. White and B. W. Chappell, "Ultrametamorphism and Granite Genesis", Tectonophysics, Vol. 43, pp. 7 - 22. 1979.

[25] B.E. John and J. Wooden, "Petrology and geochemistry of the metaluminous to peraluminous Chemehuevi Mountains Plutonic suite, Southeastern Clifornia" In: Anderson, J.L. (eds) The Nature and Origin of Cordileran Magmatism..Geological Society of America, Memoir 174,1990. pp 71-98.

[26] A. A. Beus "Distribution of Tantalum and Niobium in Muscovites of Granitic Pegmatites" Geokhimiya, No.10. pp. 1216-1220. 1966.

[27] J. I. D. Adekeye, and O. F. Akintola, "Geochemical Features of Rare Metal Pegmatites in Nasarawa Area, Central Nigerial", Journal of Mining and Geology, Vol. 43, No. 1, pp. 15-21, 2007.

[28] A.A. Elueze, "Mineralogy and chemical nature of meta-ultramafites in Nigeria schist belts, Migeria". Journal of Mining and Geology, 19, pp, 21-29. 1982.

[29] A.I. Akintola, P.R. Ikhan, O.A. Okunnlola, G.O. Akintola and O.O Oyebolu, "Compositional features of precambrain pegmatites of Ago-Iwoye area South Western Nigeria". Journal of ecology and natural environment, Vol. 4(3). pp 71-87. 2011, belts. Journal of mining and Geology 18. pp 31-36, 1981.

[30] O.A. Okunlola and E.B. Somarin, "Compositional features of Precambrian pegmatites of Itakpe area, central Nigeria". Global Journal of geological society.Vol.4 (2). pp 221-230, 2005.

[31] P Moller, and G. Morteani, "Geochemical exploration guide for tantalum pegmatites". Economic Geology, Vol. 42. Pp 1885- 1897. 1987. 